\title{
Alder pollen concentrations in the air during snowfall
}

\author{
I. Kasprzyk ${ }^{1} \cdot$ K. Borycka ${ }^{1}$
}

Received: 30 November 2018 /Revised: 29 July 2019 / Accepted: 1 August 2019/Published online: 6 September 2019

(C) The Author(s) 2019

\begin{abstract}
The focus of our study was airborne alder pollen because it is one of the main causes of inhalant allergies in many countries in the Northern Hemisphere. The main research setback was pollen concentrations during snowfall. Analyses from a 21-year database showed that the hourly patterns of occurrence of airborne Alnus pollen during snowfall differ. Snowfall can cause a decrease in pollen concentrations in the air that may persist for several hours. However, during the snowfall period of 2018, an increase in pollen concentrations was observed. High temperatures during the days preceding snowfall stimulate thermal currents, and pollen could become airborne. During snowfall, airborne pollen grains are supposedly washed out of the atmosphere and numerous pollen grains are deposited on the snow surface. Hypotheses about the long-distance transport of pollen have also been verified. Back-trajectory analysis has revealed that air masses from Belarus and Ukraine were transported to Rzeszow. We found that the influence of snowfall on pollen concentrations is ambiguous and individuals prone to allergies also notice symptoms on days with snowfall and temperatures below zero.
\end{abstract}

\section{Introduction}

In Europe, alder (Alnus) pollen is characterised by the high clinical relevance of its allergens, especially owing to its cross-reactivity with the allergens of hazel and birch (Ebner et al. 1993). As a result, there have been numerous studies concerned with seasonal pollen concentrations, the impact of weather, and modelling of airborne alder pollen (RodriguezRajo et al. 2009; Nowosad et al. 2018). In a temperate climate, the average start dates of the Alnus pollen season are highly variable, ranging from December to March or April (Jantunen et al. 2012; Gehrig et al. 2015; Dąbrowska-Zapart et al. 2018). In Poland, the pollen season starts on average at the beginning of March and lasts until the second half of April, while maximum pollen concentrations occur during the last 10 days of March (Nowosad et al. 2015).

The most important factors affecting the intensity and course of the alder pollen season are the air and ground temperature on the days preceding and during pollen release, as well as the air humidity, whereas the influence of other factors is weaker or irrelevant (Borycka and Kasprzyk 2018b;

I. Kasprzyk

idalia@univ.rzeszow.pl

1 Department of Environmental Monitoring, University of Rzeszow, 4 Zelwerowicza St., 35-601 Rzeszow, Poland
Dąbrowska-Zapart et al. 2018). As in the case of many pollen taxa, the effect of precipitation is unclear (Malkiewicz et al. 2016). Most often, it causes a decrease in pollen concentrations (Piotrowska-Weryszko 2013), but reports on increases in pollen concentrations before or during rainfall or thunderstorms have been identified (Norris-Hill and Emberlin 1993; Rathnayake et al. 2017; Borycka and Kasprzyk 2018a). These concentrations can be high enough to provoke allergy symptoms (D'Amato et al. 2016).

Very little information exists regarding the aerobiological situation during winter (Janzon 1981). If the soil temperature is negative, the pollination of alder is delayed and snow cover thickness minimally affects the concentration of pollen grains (Dąbrowska-Zapart et al. 2018). Škvarenina et al. (2017) showed that the occurrence of snow cover delays the start of pollen release, and thus, the beginning of the pollen season. Frenz and Murray (1997) found the pollen of several taxa in the air of Minneapolis (cold temperate climate) during the winter, when plants do not flower, and pollen grains are mostly derived from secondary deposition. A completely different case is the presence of pollen in the air during winter (thermal or phenological winter), when plants have already started to pollinate in situ. Such situations are not rare in a transitional warm temperate climate at the beginning of the pollination period and are most often associated with short-term warming during winter (Borycka and Kasprzyk 2018b).

The occurrence of airborne pollen during snowfall has not been previously described. Snowfall presumably removes 
pollen from the atmosphere, which results in a noticeable reduction in its atmospheric concentrations. Here, we examine airborne Alnus pollen in relation to meteorological parameters, with particular emphasis on days with snowfall.

\section{Materials and methods}

The study was conducted in Rzeszow $\left(50^{\circ} 02^{\prime} 28^{\prime \prime} \mathrm{E}\right.$; Fig. 1A), a city located in south-eastern Poland within two mesoregions: the Carpathians and their foothills. Such locations in the study area are known to have large climatic gradients (Romer 1949). This region is located in a temperate warm climate of a transitional nature. In the period 19972016, the average annual temperature was $8.7^{\circ} \mathrm{C}$ and the annual rainfall was $692 \mathrm{~mm}$ (Fig. 1B). On average, there are 166 days of rain and 58 days of snow within a year (ranging from 38 to 83 days). The mean temperature in the coldest month, January, is $-2.0{ }^{\circ} \mathrm{C}$, while in the warmest month, July, it is $19.1{ }^{\circ} \mathrm{C}$. The most important month for the study was March - the period of full alder pollination. The average temperature during this month is $3.4^{\circ} \mathrm{C}$, with an average of 7.4 frost days (ranging from 19 in 2006 to 0 in 2007 and 2014).

Aerobiological monitoring was conducted from 1997 using volumetric pollen traps. The traps were located downtown (A1) and in the suburbs (A2-from 2014) (Fig. 1 C, D). Both traps were at a height of $12 \mathrm{~m}$ above ground level (a.g.l). The monitoring stations were about $3 \mathrm{~km}$ from each other. Each day, data were expressed as the average daily concentration per cubic metre of air (pollen grains $\mathrm{m}^{-3}$; Galán et al. 2017), and hourly concentrations per cubic metre of air for selected days. For data analysis, we selected days during the main Alnus pollen season, on which snowfall was detected, and simultaneously, the concentration of alder pollen grains exceeded 45 pollen grains $\mathrm{m}^{-3}$, which is the threshold

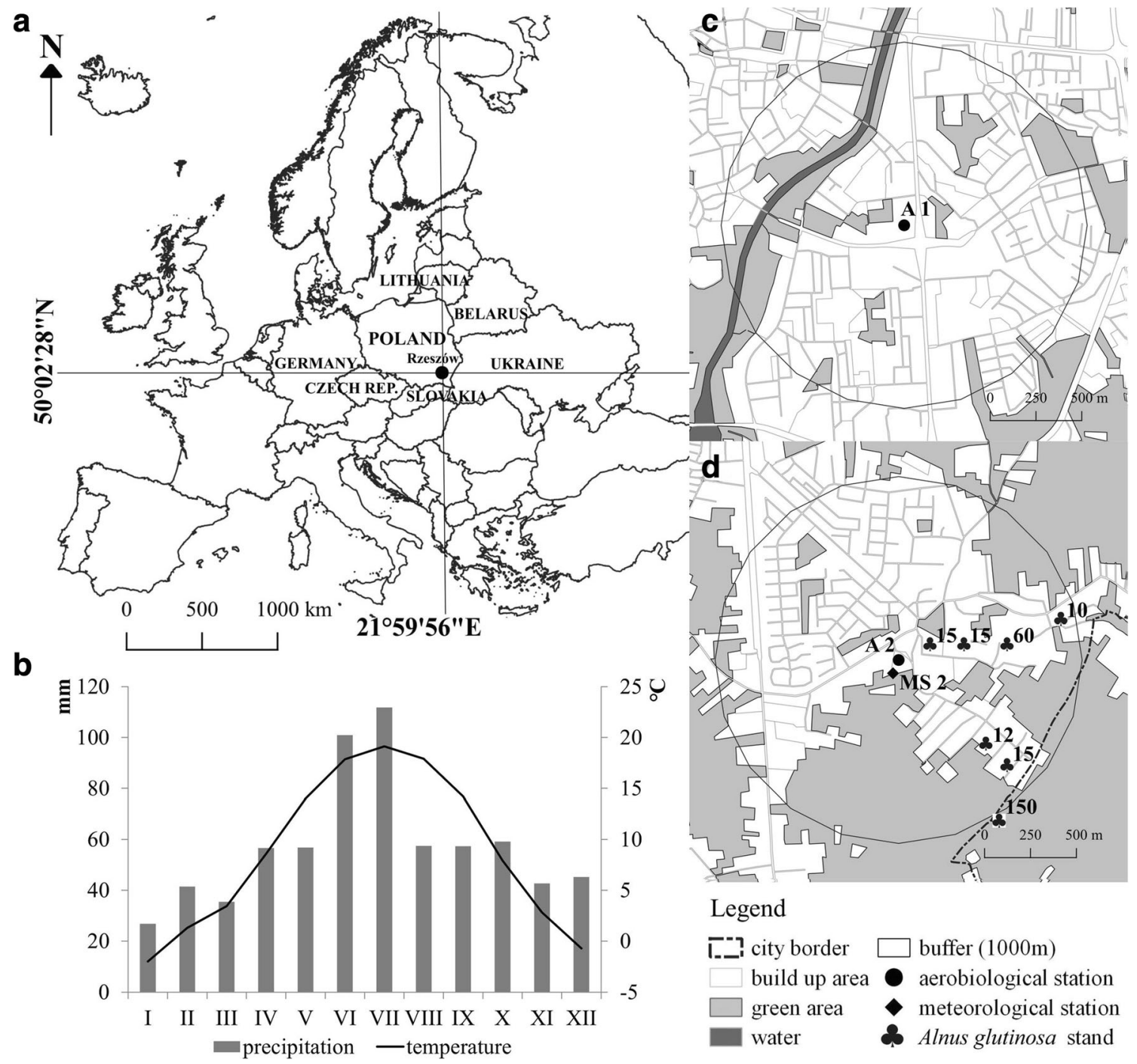

Fig. 1 The location of Rzeszow shown on the map of Europe (A), the climate diagram for 1997-2016 (B), the location of the aerobiological stations and the number of alder trees in the city $(\mathrm{C}, \mathrm{D})$ 
for allergy symptoms (Rapiejko et al. 2004). Black alder (Alnus glutinosa (L.)) is frequently found in Rzeszow, and the number of trees near the pollen traps differed - there were no individuals within a radius of $1 \mathrm{~km}$ from $\mathrm{A} 1$ and more than 150 individuals within a similar radius from A2 (Fig. 1 C, D).

The hourly concentrations recorded on 17 and 18 March 2018 from the two stations were compared. The data were not normally distributed; thus, non-parametric tests were used in the statistical analysis. Spearman's rank correlation test was used to check the time synchronisation and the Wilcoxon test was used to determine whether the hourly concentrations at corresponding hours differed.

The meteorological parameters were obtained from the National Institute of Meteorology and Water Management and measured by the meteorological station located at the Rzeszow-Jasionka airport, situated almost $10 \mathrm{~km}$ from the city centre (for 2001 and 2006). A second station was close to the A2 location (for 2018).

The data regarding the type and intensity of precipitation at hourly intervals were obtained from SYNOP (surface synoptic observations) reports (for 2001, 2006, and 2018). The precipitation data from SYNOP reports were available on the OGIMET server (OGIMET 2018) for the RzeszowJasionka meteorological station. The numerical reports were decoded, according to the international FM-12 SYNOP key, into the following categories of precipitation: continuous light rain, light rain and snow, light snow showers, moderate to heavy snow showers, snow showers, intermittent light snow, continuous light snow, and continuous moderate snow (http://people.bolyai.elte.hu/ usrin/synop.pdf).

The preliminary analysis indicated the possibility of long-distance transport of alder pollen to Rzeszow from other regions on 17 and 18 March 2018. To verify this assumption, backward air mass trajectories were calculated using the Hybrid Single-Particle Lagrangian Integrated Trajectory model (HYSPLIT) (Rolph et al. 2017). The back trajectories were computed using the Global Data Assimilation System (GDAS) meteorological data of $1^{\circ} \times 1^{\circ}$ spatial resolution (from 2004 onwards). The trajectories were calculated bi-hourly up to 24 or $48 \mathrm{~h}$ back in time, ending at 10:00 h UTC on 17 March, and 23:00 h UTC on 18 March. To analyse the movement of air masses, two trajectory heights were selected: $500 \mathrm{~m}$ and $1000 \mathrm{~m}$ a.g.l. All times (excluding backward trajectory analysis) were presented as Central European Summer Time $(\mathrm{UTC}+2)$.

In 2018, the day after the snowfall stopped, pollen grains deposited on the snow cover were analysed. A 2-3-cm layer of snow was collected at three spots near each monitoring station. A volume of $180 \mathrm{~mL}$ of melted snow was centrifuged and decanted. Microscope slides were then prepared from $30 \mu \mathrm{L}$ of the sediment. Pollen grains were counted from $43.2 \mathrm{~mm}^{2}$ of the total area of the microscope slide.

\section{Results}

\section{Pollen concentration in the air}

Following analysis of the 21-year database, only 3 days were found to have fulfilled the criteria assumed in the methodology. Snowfall was observed on each of the 3 days, but the hourly patterns of airborne Alnus pollen differed:

(A) Alnus pollen concentrations showed an evident decline during and after snowfall (20 March 2001);

(B) After snowfall, the Alnus pollen concentration increased rapidly with increasing temperature (6 April 2006);

(C) Alnus pollen concentrations increased during snowfall (17-18 March 2018).

\section{Episode A—20 March 2001}

In 2001, the period of continuous occurrence of Alnus pollen in the air began on 7 February, and until the end of that month, the daily concentrations were below 20 pollen grains $\mathrm{m}^{-3}$. From the beginning of March, the daily concentration gradually increased, reaching a maximum on 12 March of 427 pollen grains $\mathrm{m}^{-3}$. During the first half of March, the maximum temperatures exceeded $10^{\circ} \mathrm{C}$, while the minimum temperatures were always above zero. After a few days of low concentrations (from 15 to 18 March), a two-day increase was observed, whereas on the following days, either no pollen was detected in the air, or the concentrations were very low. This reduction was associated with a snowfall event on 20 March (Fig. 2A). Examination of the diurnal variations in the Alnus pollen count on 20 March 2001 showed that the concentration peaked at 1:00 h. A light snow shower was observed between 1:00 $\mathrm{h}$ and 2:00 $\mathrm{h}$, resulting in a decline in the concentration during the next hour. At 9:00 h, a moderate snow shower was observed, and the concentration showed an evident decline. In the following hours with light snowfall, the concentrations gradually decreased. After $6 \mathrm{~h}$ of snow showers, the decline was evident, the temperature decreased, the wind was westerly, and its speed was increased (Fig. 2B).

\section{Episode B-6 April 2006}

During March and April 2006, the maximum temperatures were very high, exceeding $15^{\circ} \mathrm{C}$. From 3 to 4 April, the daily pollen concentrations exceeded 200 pollen grains $\mathrm{m}^{-3}$. However, owing to a lack of data over several days, it was difficult to determine whether these were the highest seasonal concentrations. In the following days, the daily concentrations decreased, regardless of the snowfall recorded on 6 April; nevertheless, for several consecutive days, the daily concentrations exceeded the threshold value for allergies (Fig. 2C). 
Fig. 2 The daily (A, C, E) and diurnal (B, D, F) concentrations of alder pollen grains in downtown (A1) in 2001 and 2006 as well as in downtown (A1) and the suburbs (A2) in 2018 in Rzeszow relative to meteorological parameters $\mathbf{a}_{\text {示 }}$
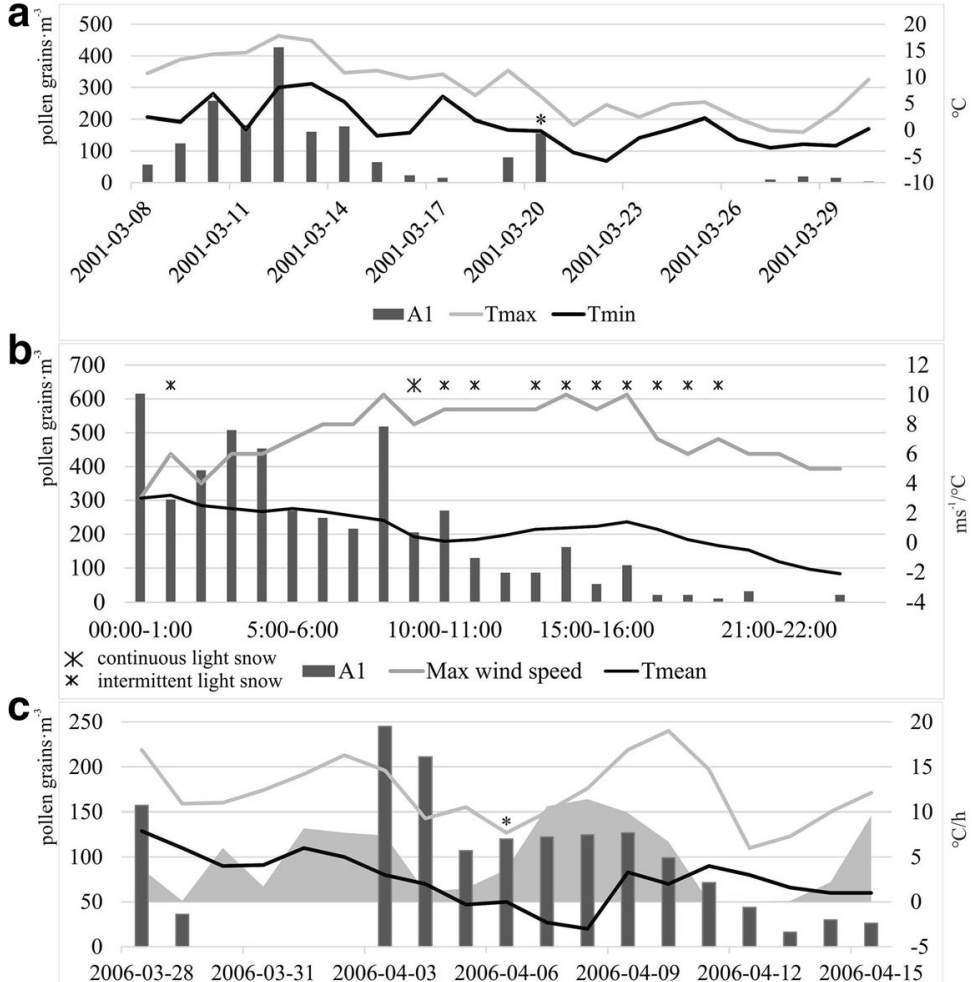

sun hours $=\mathrm{A} 1-\mathrm{Tmax}-\mathrm{Tmin}$
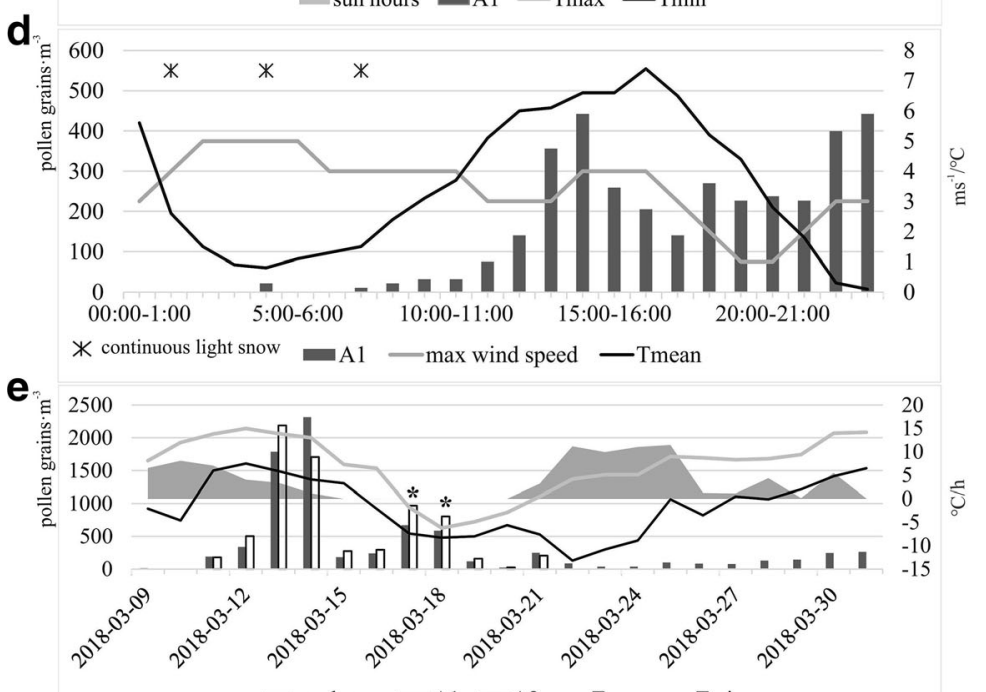

f

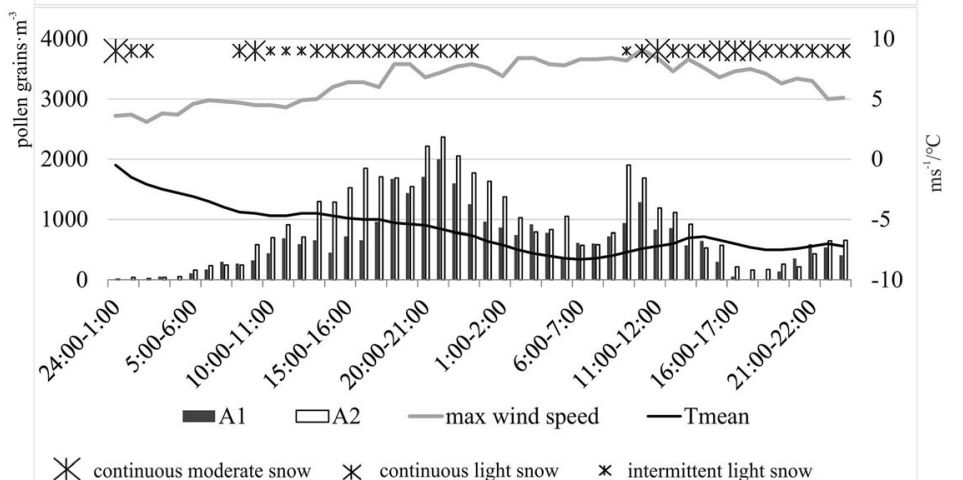


On 6 April, continuous light snow or snow with rain was observed every $3 \mathrm{~h}$ from 1:00 $\mathrm{h}$ to 8:00 $\mathrm{h}$. The mean temperature was below $3{ }^{\circ} \mathrm{C}$ and airborne pollen occurred sporadically. Shortly after snowfall, the temperature and sunlight hours were evidently increased simultaneously with an increase in pollen concentrations. The maximum pollen concentrations were observed from 14:00 $\mathrm{h}$ to $15: 00 \mathrm{~h}$ and from 23:00 h to 0:00 h (Fig. 2D).

\section{Episode C-17-18 March 2018}

In 2018, the first alder pollen grains in the atmosphere of Rzeszow appeared at the beginning of February. The continuous period of their occurrence started on $9 \mathrm{March}$, and after a few warm, sunny days (temperatures above $10{ }^{\circ} \mathrm{C}$ ), pollen concentrations peaked on 13-14 March. The maximum values ranged from 1707 to 2317 pollen grains $\mathrm{m}^{-3}$ (Fig. 2E). Over the following 2 days, the temperature decreased and the concentrations at both stations (A1 and A2) were about 10 times lower. On 17 and $18 \mathrm{March}$, the minimum daily temperature was below $-7{ }^{\circ} \mathrm{C}$, while the actual duration of sunlight was zero. Strong wind, snowfall, or snow with rain was recorded. Despite the negative temperatures and snowstorm, the concentrations increased up to 671 pollen grains $\mathrm{m}^{-3}$ downtown and 969 pollen grains $\mathrm{m}^{-3}$ in the suburbs (Fig. 2E). On these days, the concentrations at corresponding hours were significantly increased $(Z=4.831 ; p=0.000)$, but their diurnal pattern was similar, as evidenced by the high value of Spearman's rank correlation coefficient $\left(r_{\mathrm{s}}=0.911\right)$. Several hours before the snowstorm, the wind blew from the west and intensified. On 17 March, snowfall was observed almost all day, the maximum wind speed ranged from 4 to $7 \mathrm{~ms}^{-1}$, and the number of pollen grains was increased, reaching the highest value at 22:00 $\mathrm{h}$. In the following hours, the wind was still strong, greater than $8 \mathrm{~ms}^{-1}$, but changed direction towards the south, and then the south-east, and the pollen concentrations decreased. The second peak in pollen concentration was recorded from 09:00 to 11:00 h on 18 March, with the highest wind speed $\left(9 \mathrm{~ms}^{-1}\right)$ from the east, and light or moderate continuous snowfall (Fig. 2F).

The 24-h back-trajectory analysis revealed that before noon on 17 March, the air masses over Rzeszow arrived from two main directions. Firstly, from the southern direction, as far as the northern part of Romania, and secondly, from southeastern Belarus, as well as from the north-western part of Ukraine. On 17 and 18 March, the air mass influxes in Rzeszow emanated from north-western Russia, passing through the western part of Russia, the northern part of Ukraine, and south-eastern Belarus (the 48-h back-trajectory ended around midnight on $18 \mathrm{March}$ ). The trajectory heights showed that the majority of air masses that had arrived over Rzeszow before noon on 17 March moved upward, towards the city. However, a large part of the air masses detected during the afternoon on 17 and 18 March descended from higher altitudes (Fig. 3).

\section{Pollen deposition on snow}

Pollen grains were detected both in the air and on the snow surface. The numbers of pollen grains collected in various snow samples showed distinct differences. In the city centre near station A1, where no alder trees were observed, the mean number of pollen grains was more than eight times lower than in the suburbs, near station A2. It is noteworthy that the two samples collected in the city centre, near wide roads-A1/1 and A1/3 - comprised single grains; whereas sample A1/2 was collected between blocks of flats, where 69 grains were found (Table 1).

\section{Discussion}

The transitional character of the Polish climate generates strong variability in weather conditions in the early spring (Nowosad et al. 2015). As we have observed in an earlier study, the interruption of alder pollination by the sudden return of winter is not a rare phenomenon and can cause inflorescences to be destroyed by frost and snow, resulting in a noticeable reduction in pollen concentrations. On such days, single grains may be observed in the air and probably appear randomly (Puc and Kasprzyk 2013). A detailed search of the Rzeszow database revealed that on days with snowfall, daily pollen concentrations with the threshold value for severe allergy symptoms were rarely recorded. Such behaviour occurred in Rzeszow only three times over the 20-year study period. On those days, the diurnal patterns varied, indicating the difficult-to-predict effects of different types of snowfall on airborne pollen concentrations. This difficulty also arises from the overall impact of weather conditions at a given time and is not reflective of the effects of snowfall alone (Borycka and Kasprzyk 2018b). A detailed synoptic analysis demonstrated that relatively high alder pollen concentrations could persist both during snow showers (the situation in 2001), as well as continuous and moderate snowfall (the situation in 2018). Nonetheless, the long-term data of such situations are sporadic.

Among the three episodes described above, that during 2018 is the most interesting, as it is the only case in which a reduction in Alnus pollen concentration during snowfall was observed for a dozen or so hours with a negative temperature, and an increase in the concentrations was recorded during continuous light snow. For the first two 10-day periods in March, weather conditions were similar across Poland. After a very frosty beginning of March, the temperature systematically increased to a maximum around 8-14 March. This 
NOAA HYSPLIT MODEL, GDAS Meteorological data

Backward trajectories

ending at 17 March 2018 10:00 UTC

duration: 24 hrs; a new trajectory every $2 \mathrm{hrs}$

height: $500 \mathrm{~m}$ agl

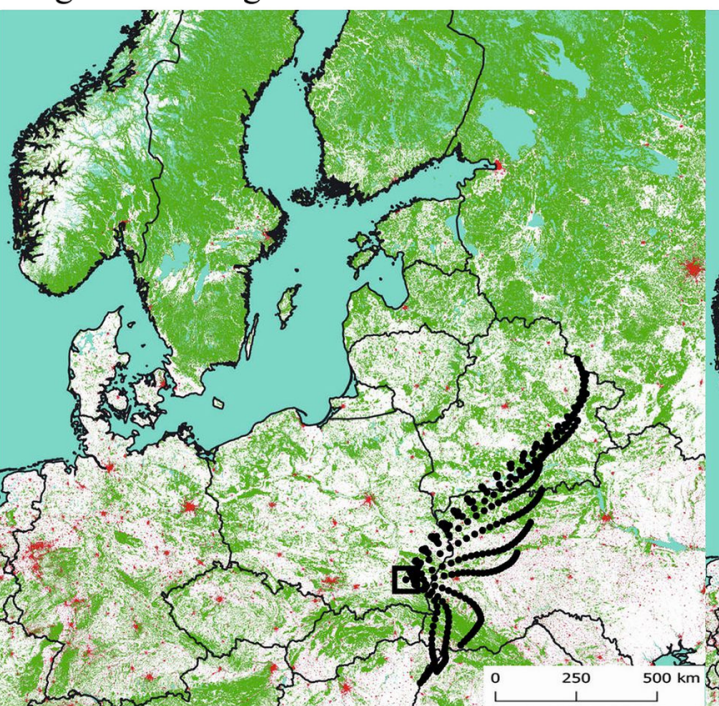



Backward trajectories

ending at 17 March 2018 10:00 UTC

duration: $24 \mathrm{hrs}$; a new trajectory every $2 \mathrm{hrs}$ height: $1000 \mathrm{~m} \mathrm{agl}$
Backward trajectories

ending at 18 March 2018 23:00 UTC

duration: 48 hrs; a new trajectory every 4 hrs height: $500 \mathrm{~m}$ agl
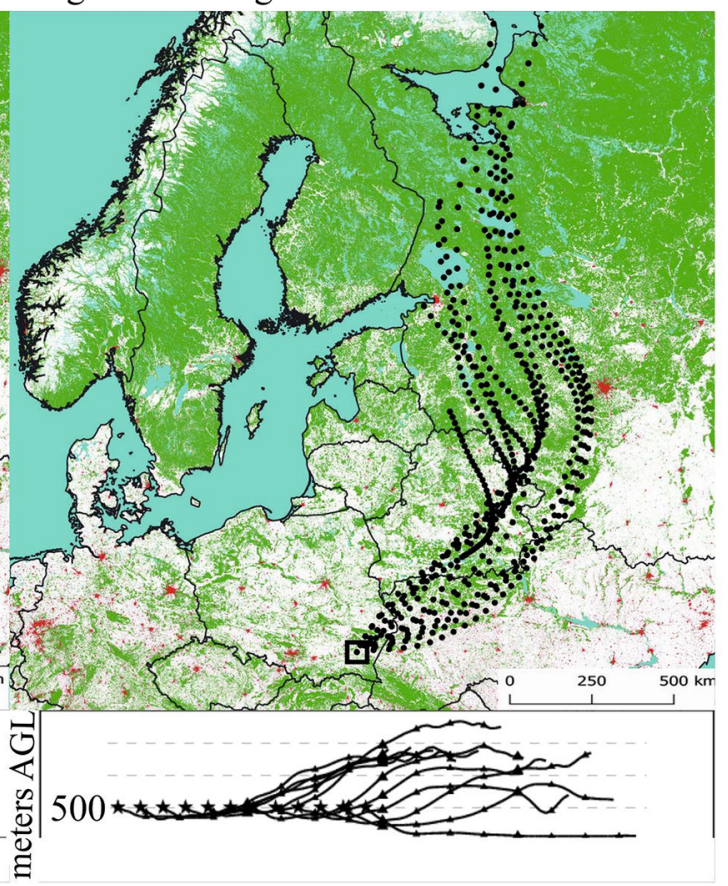

Backward trajectories

ending at 18 March 2018 23:00 UTC

duration: $48 \mathrm{hrs}$; a new trajectory every $4 \mathrm{hrs}$ height: $1000 \mathrm{~m} \mathrm{agl}$

\section{height. 1000 m agl}
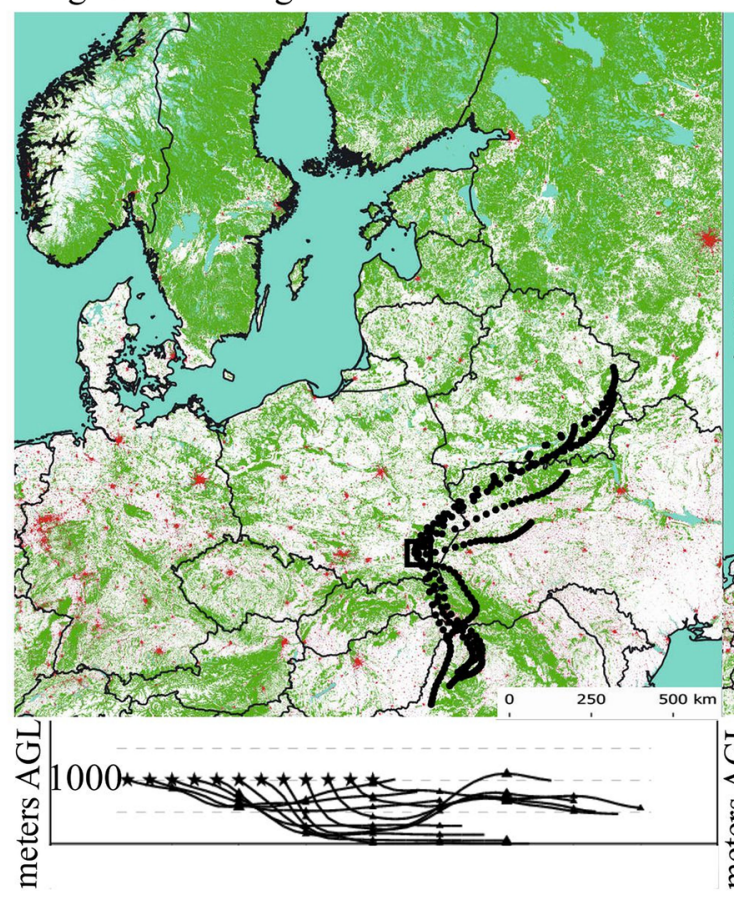

LEGEND: $\square$ Rzeszów $\quad$ trajectory $\square$ urban area $\square$ water $\square$ forest area 
Fig. 3 Backward trajectories (BT) calculated for Rzeszow at two starting heights (500 and $1000 \mathrm{~m}$ a.g.1): 24-h BT ending at 10:00 am on 17th March 2018 and 48-h BT ending at 11:00 pm on 18th March 2018

contributed to a very similar pattern of pollen seasons in almost every region of Poland (Rapiejko et al. 2018). We think that such a remarkable increase in temperature, as well as the high solar radiation and extended duration of sunlight, most probably caused the intense pollen release (Bilińska et al. 2019). Furthermore, the peak airborne pollen concentrations were recorded on the same days at almost all locations (Rapiejko et al. 2018). The highest maximum concentration (907 pollen grains $\mathrm{m}^{-3}$ ) was found in the south-western region, which is considered to be the warmest in Poland. However, this concentration was much lower than those recorded in Rzeszow.

Alder trees are present in large numbers near one of the monitoring sites in Rzeszow. Therefore, with such a rapid increase in temperature and the short duration of intense pollen shed, a considerable amount of pollen was presumably generated in the upper atmosphere, due to the effects of thermal currents (Zhao et al. 2014). After this period of high temperatures, snowfall occurred both in Rzeszow and across Poland. Airborne pollen grains likely fell, owing to the washout effect, and this could have caused a short-term increase in concentrations. A similar phenomenon was observed on days with convective rainfall, when during the first hours of precipitation, the concentrations were as high as (or even higher than) it was during the hours before rainfall. We observed this phenomenon (Borycka and Kasprzyk 2018a), and Norris-Hill and Emberlin (1993) made similar observations in London. The wind speed could have also affected the increase in concentrations. Wind speed promotes pollen transport, and as Norris-Hill and Emberlin (1993) claim, it increases the suction in the pollen sampler, thus increasing its sampling efficiency.

In many aerobiological studies, an unusual increase in airborne pollen concentration has been attributed to long-

Table 1 The numbers of pollen grains in snow samples (A1, A2aerobiological monitoring stations)

\begin{tabular}{lll}
\hline Location/subsample & Pollen type \\
\cline { 2 - 3 } & Alnus & Others \\
\hline A1/1 near road and buildings & 2 & 0 \\
A1/2 between blocks of flats & 69 & 4 \\
A1/3 near main, wide road & 3 & 1 \\
mean A1 & 24.7 & 1.7 \\
A2/1 near urban park & 37 & 15 \\
A2/2 in meteorological garden & 222 & 38 \\
A2/3 near small forest & 359 & 93 \\
mean A2 & 206 & 48.6 \\
\hline
\end{tabular}

distance transport. This phenomenon has been described for airborne pollen during the full growing season of various plants, e.g., Betula, Ambrosia, and Fagus (Belmonte et al. 2008; Grewling et al. 2016; Izquierdo et al. 2017). No description of similar situations during the winter or early spring seems to exist, and such a situation could have occurred in the case of Alnus in Rzeszow in 2018.

The analysis of air mass trajectories shows that on $17-$ 18 March 2018, the air masses arrived in Rzeszow from the east (Ukraine) and north-east (Belarus, Lithuania), and thus, from the regions in which snowfall was recorded and the temperature was below zero. Negative temperatures, increased air humidity during rainfall, and a short duration of sunlight promote the closing of the anthers and inhibit the release of new pollen grains into the atmosphere (Rodriguez-Rajo et al. 2009). Thus, regions located to the northeast and east of Rzeszow could not have been the source of the large amounts of pollen transported to Poland, because alder did not shed pollen intensely during 17-18 March 2018 (Ingriga Šaulienè-personal communication).

The maximum pollen concentrations in north-eastern Poland, which borders southern Lithuania and eastern Belarus, and is also known as the Polish cold pole, were recorded almost 3 weeks later than the other regions of Poland, including Rzeszow (Rapiejko et al. 2018). Dąbrowska-Zapart et al. (2018) indicated a strong relationship between alder pollen concentrations and synoptic situations. Pollen concentrations declined on days with cyclonic conditions arriving from the east and south-east, as well as anticyclonic conditions from the north and north-east. Furthermore, pollen transport due to strong winds and the high dispersion capacity of alder pollen must be considered. However, we feel that local or regional transport could have occurred, or airborne pollen might have emanated primarily from local (urban and peri-urban areas) sources, as many stands of black alder are located in Rzeszow. On days with high pollen concentrations during snowfall (during 2001 and 2018), the wind speed was much higher $\left(8-10 \mathrm{~ms}^{-1}\right)$ than on those days when pollen grains were recorded sporadically (during 2006, below $5 \mathrm{~ms}^{-1}$ ).

The theory indicating the significant role of local pollen sources seems to be confirmed by the pollen deposition on snow. In the areas of the city where alder trees are not grown, the number of pollen grains deposited on snow was remarkably lower than those recorded among samples collected at sites where alders are grown in large numbers. Similar to Bilińska et al. (2019), we assume that in spite of the enormous dispersal capacity of pollen grains, local vegetation is the main source of airborne pollen. The differences observed in the deposition of pollen among subsamples could be attributed to local conditions, such as the height and layout of buildings, and type of land use. 


\section{Conclusions}

Generally, individuals affected by allergies are believed to be unexposed to airborne pollen in the winter. Nevertheless, as we have shown, the influence of snowfall on pollen concentrations is ambiguous. It depends, among other things, on the type of snow, weather conditions before snowfall, and phase of the pollen season. In light of the present results, individuals prone to pollen allergies may experience symptoms on days with snowfall and temperatures below zero. This discovery poses a challenge for aerobiologists, who prepare pollen forecasts to predict the risks associated with allergenic alder pollen.

Open Access This article is distributed under the terms of the Creative Commons Attribution 4.0 International License (http:// creativecommons.org/licenses/by/4.0/), which permits unrestricted use, distribution, and reproduction in any medium, provided you give appropriate credit to the original author(s) and the source, provide a link to the Creative Commons license, and indicate if changes were made.

\section{References}

Belmonte J, Alarcon M, Avila A, Scialabba E, Pino D (2008) Long-range transport of beech (Fagus sylvatica L) pollen to Catalonia (northeastern Spain). Int J Biometeorol 52:675-687

Bilińska D, Kryza M, Werner M, Malkiewicz M (2019) The variability of pollen concentrations at two stations in the city of Wrockaw in Poland. Aerobiologia. https://doi.org/10.1007/s10453-019-09567-1

Borycka K, Kasprzyk I (2018a) Hourly pattern of alder and birch pollen concentrations in the air, spatial differentiation and the effect of meteorological conditions. Atmosph Environ 182:179-192

Borycka K, Kasprzyk I (2018b) Do the threats of alder and birch allergenic pollen differ within an urban area? Urban Forest Urban Green 34:281-294

D'Amato G, Vitale C, D'Amato M, Cecchi L, Liccardi G, Molino A, Vatrella A, Sanduzzi A, Maesano C, Annesi-Maesano I (2016) Thunderstorm-related asthma, what happens and why. Clin Exp Allergy 463:390-396

Dąbrowska-Zapart K, Chłopek K, Niedźwiedź T (2018) The impact of meteorological conditions on the concentration of alder pollen in Sosnowiec (Poland) in the years 1997-2017. Aerobiologia 34: 469-485. https://doi.org/10.1007/s10453-018-9524-8

Ebner C, Ferreira F, Hoffmann K, Hirschwehr R, Schenk S, Szépfalusi Z, Breiteneder H, Parronchi P, Romagnani S, Scheiner O, Kraft D (1993) $\mathrm{T}$ cell clones specific for Bet $\mathrm{v}$ I, the major birch pollen allergen, crossreact with the major allergens of hazel, Cora I, and alder Aln g I. Mol Immunol 30(15):1323-1329

Frenz DA, Murray LW (1997) An atmospheric pollen survey conducted during the winter in Minneapolis, Minnesota, USA. Grana 36:245248

Galán C, Ariatti A, Bonini M, Clot B, Crouzy B, Dahl A, FernandezGonzález D, Frenguelli G, Gehrig R, Isard S, Levetin E, Li DW, Mandrioli P, Rogers CA, Thibaudon M, Sauliene I, Skjoth C, Smith M, Sofiev M (2017) Recommended terminology for aerobiological studies. Aerobiologia 33:293-295
Gehrig R, Gassner M, Schmid-Grendelmeier P (2015) Alnus x spaethii pollen can cause allergies already at Christmas. Aerobiologia 31: 239-247

Grewling Ł, Bogawski P, Jenerowicz D, Czarnecka-Operacz M, Sikoparija B, Skjøth CA, Smith M (2016) Mesoscale atmospheric transport of ragweed pollen allergens from infected to uninfected areas. Int J Biometeorol 60(10):1493-1500

Izquierdo R, Alarcon M, Mazón J, Pino D, De Linares C, Aguinagalde X, Belmonte J (2017) Are the Pyrenees a barrier for the transport of birch (Betula) pollen from Central Europe to the Iberian Peninsula? Scienc Total Environ 575:1183-1196

Jantunen J, Saarinen K, Rantio-Lehtimäki A (2012) Allergy symptoms in relation to alder and birch pollen concentrations in Finland. Aerobiologia 28:169-176

Janzon, LA (1981) Airborne pollen grains under winter conditions Grana 203: $183-185$

Malkiewicz M, Drzeniecka-Osiadacz A, Krynicka J (2016) The dynamics of the Corylus, Alnus, and Betula pollen seasons in the context of climate change (SW Poland). Sci Total Environ 573:740-750

Norris-Hill J, Emberlin J (1993) The incidence of increased pollen concentrations during rainfall in the air of London. Aerobiologia 91:2732

Nowosad J, Stach A, Kasprzyk I et al (2015) Temporal and spatiotemporal autocorrelation of daily concentrations of Alnus, Betula and Corylus pollen in Poland. Aerobiologia 312:159-177

Nowosad J, Stach A, Kasprzyk I et al (2018) Statistical techniques for modelling of Corylus, Alnus, and Betula pollen concentration in the air. Aerobiologia. https://doi.org/10.1007/s10453-018-9514-x

OGIMET (2018) Queries about Synop reports http://www.ogimet.com/ synops.phtml.en

Piotrowska-Weryszko K (2013) The effect of the meteorological factors on the Alnus pollen season in Lublin (Poland). Grana 52(3):221-228

Puc M, Kasprzyk I (2013) The patterns of Corylus and Alnus pollen seasons and pollination periods in two Polish cities located in different climatic regions. Aerobiologia 29(4):495-511

Rapiejko P, Lipiec A, Wojdas A, Jurkiewicz D (2004) Threshold pollen concentration necessary to evoke allergic symptoms. Int Rev Allergol Clinic Immunol 103:91-94

Rapiejko P, Puc M, Piotrowska-Weryszko K, Konarska A, Siergiejko G, Świebocka EM, Rapiejko A, Myszkowska D, Ziemianin M, Kotrych D, Jurkiewicz D, Wieczorkiewicz A, Kalinowska E (2018) Alder pollen season in Poland in 2018. Alergoprofil 1(14): 27-23 [in Polish]

Rathnayake CM, Metwali N, Jayarathne T, Kettler J, Huang Y, Thorne PS, O'Shaughnessy PT, Stone EA (2017) Influence of rain on the abundance of bioaerosols in fine and coarse particles. Atmos Chem Phys 17:2459-2475

Rodriguez-Rajo FJ, Grewling L, Stach A, Smith M (2009) Factors involved in the phenological mechanism of Alnus flowering in Central Europe. Ann Agric Environ Med 16(2):277-284

Rolph G, Stein A, Stunder B (2017) Real-time environmental applications and display system: READY. Environ Modell Softw 95:210 228

Romer E (1949) Climate regions of Poland. Prace Wrocławskiego Towarzystwa Naukowego, Seria B 16:3-28 [in Polish]

Škvarenina J, Borsanyi P, Šiška B (2017) Influence of snow cover and winter air temperatures on flowering of European hazel Corylus avellana (L) in Northern Carpathians. In: Šiška B (ed) Snow an ecological phenomenon Smolenice, Slovakia, 19th -21 st September, 2017

Zhao L, Lee X, Smith RB, Oleson K (2014) Strong contributions of local background climate to urban heat islands. Nature 5117508:216-219 